\title{
液体クロマトグラフ質量分析法を用いた 総ミクロシスチンの定量法の開発
}

\author{
高木 博夫 ${ }^{1)}$, 白井 美幸 ${ }^{2)}$, 佐野 友春 ${ }^{12}$, 彼谷 邦光 ${ }^{3)}$ \\ ${ }^{1)}$ 国立環境研究所（テ305-8506 茨城県つくば市小野川16-2） \\ ${ }^{2)}$ (株) 環境研究センター（３05-0857 茨城県つくば市羽成3-1） \\ ${ }^{3}$ 東北大学大学院環境科学研究科（９80-8579 宮城県仙台市青葉区荒巻字青葉20）
}

[平成16年 4 月 7 日受理］

\section{An Improved Method of the Total Microcystin Determination using Reversed-phase Liquid Chromatography Mass Spectrometry}

\author{
Hiroo TAKAGI ${ }^{1)}$, Miyuki SHIRAI ${ }^{2)}$, Tomoharu $\mathrm{SANO}^{1)}$ and Kunimitsu KAYA ${ }^{3)}$ \\ ${ }^{1)}$ National Institute for Environmental Studies \\ (16-2 Onogawa, Tsukuba, Ibaraki 305-8506) \\ ${ }^{2)}$ Environmetal Research Center Co., Ltd \\ (3-1 Hanare, Tsukuba, Ibaraki 305-0857) \\ ${ }^{3)}$ Tohoku University, Graduate School of Environmental Studies \\ (20 Aramaki-aza-aoba, Aoba-ku, Sendai, Miyagi 980-8579)
}

[Received April 7, 2004]

\begin{abstract}
Summary
Microcystins are hepatotoxic cyclic heptapeptides produced by cyanobacteria. The World Health Organization (WHO) guideline has shown that microcystin-LR content in drinking water should be below $1 \mu \mathrm{g} / \ell$. However, over 70 variants of microcystin including microcyatin-LR have been identified in the world, and their toxicities and $\mathrm{LD}_{50}$ are similar to those of microcystin-LR. Therefore, we thought that total microcystin content in drinking water should be determined. Total microcystin can be determined by the MMPB method. However, the method requires some skillful handling procedure.

In this paper, we improved the procedure of the MMPB method, and established a simple determination system for total microcystins. The procedures of the oxidation and the solidphase extraction in our original MMPB method were improved. By these improvements, the recovery of MMPB was reached to over $70 \%$ and was steady. As the result, $10 \mathrm{pg}$ of MMPB (0.1 $\mu \mathrm{g}$ microcystin/50 me sample water) can be determined by this improved method.
\end{abstract}

Key words: microcystin, MMPB, 2-methyl-3-methoxy-4-phenylbutyricacid, LC/MS, cyanobacteria 


\section{1.はじめに}

藍藻類により生産されるミクロシスチンは, 肝臓毒を 有することが知られて㧍り，WHO では飲料水中のガイ ドラインとしてミクロシスチン-LR $1 \mu \mathrm{g} / \ell$ を勧告して いる1。欧米などにおいては，ミクロシスチン-LRの量 がアオコに含まれるミクロシスチンの中では最も多いと され抄り2)，ミクロシスチン-LRについての研究デー夕 が十分蓄積されていたため, WHO の勧告はミクロシス チン-LRについてなされた。日本においてはミクロシス チン-LRが30\%程度, ミクロシスチン-RR が50\%程度, ミクロシスチン-YRが $14 \%$ 程度を占めているとされてい る3.4)。一方，マウスの $\mathrm{LD}_{50}$ による毒性が，ミクロシスチ ン-LRを 1 とするとミクロシスチン-RR はその $1 / 2$ 程度, ミクロシスチン-YRはミクロシスチン-LRの 7 割程度で ある5.6)ことから，日本においてはミクロシスチン-LRの みの測定では，アオコ中の毒性の約50\%としか評価され ていないことになる。一方，ミクロシスチンには，70種 以上の同族体が存在することがすでに知られておりり, それらをすべて分離定量することは困難である。そのた め, 上水試験方法等には, 高速液体クロマトグラフ法 （HPLC）を用いてLR, RR, YRの 3 種のミクロシスチン を測定する手法が示されている ${ }^{8)}$ 。また，高速液体ク口 マトグラフィー/質量分析装置（LC/MS）の普及に伴い これらを用いた分析方法の検討が進み，その有效性が示 されているが，一般的な定量分析としては標準物質のあ
るミクロシスチン-LR, RR, YR 等の分析法の検討にとど まっている ${ }^{910)}$ 。一方では, 総ミクロシスチン量を測定す る試みも行われ, L. Spoof ら ${ }^{11}$ は93の環境試料について, HPLC-UV 法と LC/MS 法を用いて10種のミクロシスチン を測定し，市販のELISA法を用いて測定した総ミクロシ スチン量の測定結果と比較している。ELISA 法の測定値 はHPLC を用いた方法の值の60から $70 \%$ を示し, ミクロ シスチンの種類によって抗体との交差反応性が異なるた めと結論付けている。プロテインホスファターゼ $2 \mathrm{~A}$ （PP2A）活性阻害を用いて，トータルの毒性をミクロシ スチン-LR 当量の形で評価する手法も検討されてい る ${ }^{12}$ 。PP2Aの活性阻害は，ミクロシスチン-LRが最も大 きいことから，PP2Aにより求められた総ミクロシスチ ン量は HPLCで求めた総量に比べ低めに出ることが明ら かにされている。

このように，ミクロシスチン量を把握する種々の方法 が試みられている中，ミクロシスチンを酸化分解するこ とで生成する Adda と呼ばれているミクロシスチン同族 体に共通したユニットである2-メチル-3-メトキシ-4フェニル酪酸（MMPB）を定量し（Fig. 1)，最も毒性の 強いミクロシスチン-LRに換算した総ミクロシスチン量 として測定する方法が提唱されている ${ }^{13)}$ 。定量方法に は，MMPB を誘導体化した後ガスクロマトグラフ質量 分析法を用いる方法及び HPLC-UV 検出器を用いて直接 測定する方法などが報告されている ${ }^{14)}$ 。誘導体化法は, 誘導体化の効率の再現性等を考慮しなければならず操作

microcystin
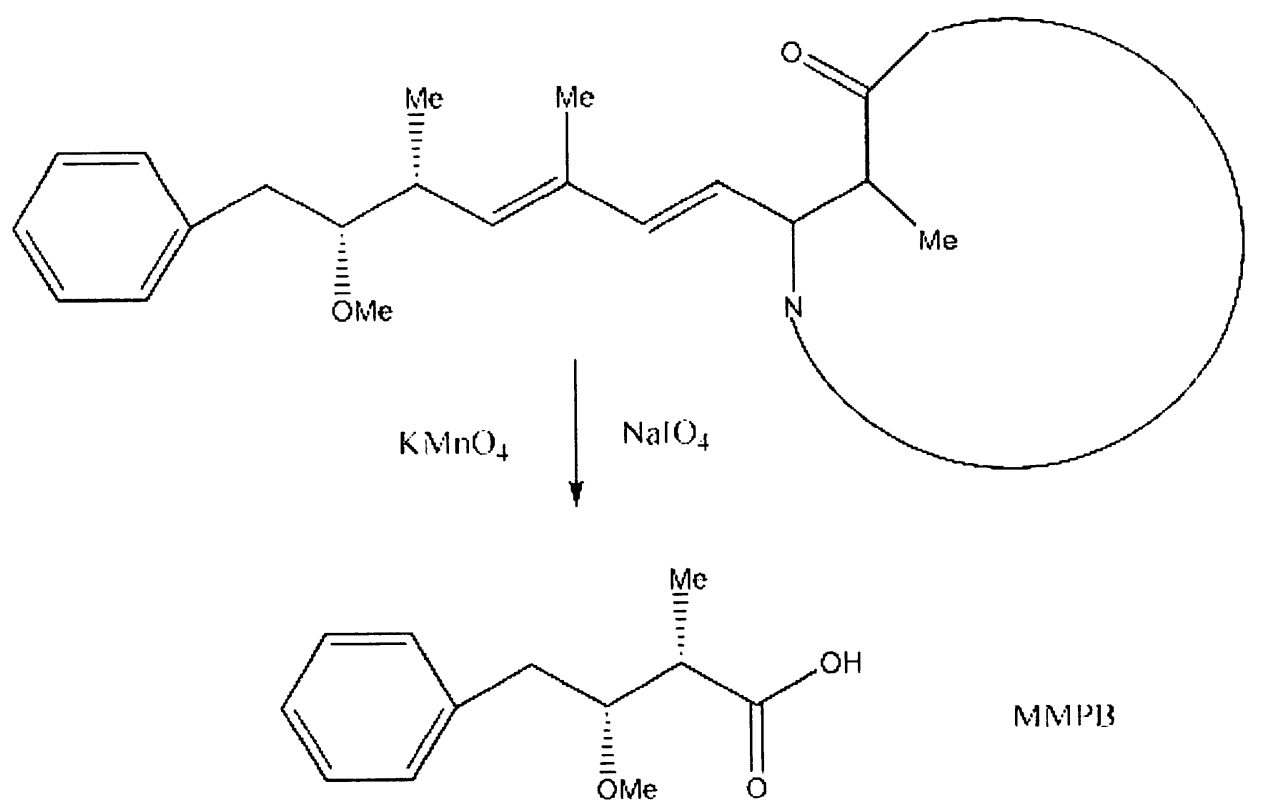

MNIPI3

Fig. 1 Formation of MMPB from microcystin by the oxidation 
が煩雑である。また，HPLC-UV 法は，感度が低くバック グラウンドの影響を受けやすいことが指摘されている。

そこで, 本研究では LC/MS 法を用いて MMPB の定量 を行う方法について検討した。さらに, 従来から提案さ れている酸化分解法および固相抽出方法についても検討 を加えた。

\section{2. 実験方法}

\section{1 試薬および測定方法}

ミクロシスチン-LR 標準試料は, ミクロキステス・ビ リデス (NIES 102) より抽出, 分離精製4) 分光光度計 (島津製作所 紫外可視分光光度計 UV-160 波長238nm $\varepsilon$ 30900）にて濃度を決定したものを使用し た。定量用標準物質として2-メチル-3-メトキシー4フェニル酪酸 (MMPB) および MMPB-d3（和光純 薬 標準品) を用いた。ミクロシスチンの酸化分解に は, 過マンガン酸カリウム, 過よう素酸ナトリウム, リ ン酸, 炭酸カリウム, 亜硫酸水素ナトリウム（和光純 薬 特級) を, 高速液体クロマトグラフ (HPLC) には, メ夕ノール, アセトニトリル (和光純薬 HPLC用), 酢 酸（和光純薬 特級）を用いた。固相抽出には, メ夕ク リレート系スチレンジビニルベンゼン共重合体カート リッジ（ジーエルサイエンス製 InertSep RP-1, 250mg/ $6 \mathrm{~m} \ell$ および30mg/ $1 \mathrm{~m} \ell)$ を用いた。

LC/MS の分析条件を Table 1 に示した。

\section{2 分析法}

分析法の概要を Fig. 2 に示す。検討内容の詳細は, 次 のとおりである。

\section{2. 1 MMPB 分析条件の検討}

MMPB ナトリウム塩 $1 \mathrm{mg}$ を正確にメスフラスコ $10 \mathrm{~m} \ell$ に採り, $50 \%$ メノール水溶液を加えて全量を $10 \mathrm{~m} \ell(100 \mu \mathrm{g} / \mathrm{m} \ell)$ とした。これを適宜希釈し所定の濃 度とした。

HPLCの最適分析条件を決定するために, 移動相の $0.001 \%$ 酢酸とアセトニトリルの濃度比を50/50，60/40に したものおよびアセトニトリル濃度を $20 \%$ から $80 \%$ まで 6 分間で直線的に変化させたグラジェント法の 3 種で MMPB の分析を行い移動相の最適比率を検討した。

定量下限值を決定するためにMMPBの注入量を $160 \mathrm{pg}, 80 \mathrm{pg}, 40 \mathrm{pg}, 20 \mathrm{pg}$ および10pg の 5 段階で変化さ せ，各注入量を 3 回測定し再現性を検討した。

2. 2 . 2 ミクロシスチン-LR の酸化分解方法の検討

ミクロシスチン-LR 標準試料の $20 \%$ メノール水溶液 $100 \mu \ell$ に $0.5 \mathrm{M} \mathrm{K}_{2} \mathrm{CO}_{3} 400 \mu \ell$ を加え, これを水冷し, 酸 化分解のための試料とした。

\section{2.3 酸化剤添加量の検討}

必要とされる酸化剂の量を検討するために，氷冷した $0.025 \mathrm{M}$ 過マンガン酸カリウム $\left(\mathrm{KMnO}_{4}\right)$ および飽和 過よう素酸ナトリウム $\left(\mathrm{NaIO}_{4}\right)$ の添加量を, それぞれ $500 \mu \ell, 50 \mu \ell$ から 2 倍, 3 倍及び 4 倍と増加させ MMPB の収率を検討した。

\section{2.4 酸化反応条件の検討}

酸化反応条件の MMPB 収率に対する影響を検討する ために, 反応温度, 攪拌条件等を以下の 5 種の条件で 行った。

1. 水水中に 1 時間保持した。その後, 水水から出 し, 室温に 3 時間保持した（30分に 1 回程度の頻度

Table1 LC/MS Conditions for MMPB determination

\author{
MS Condition \\ Instrument : LCMS-2010A (Shimadzu Corp.) \\ Ionization mode : ESI negative \\ $\operatorname{SIM}(\mathrm{m} / \mathrm{z}) \quad:$ MMPB- $d 0207 、$ MMPB- $d 3210$ \\ Nebulizer gas $: \mathrm{N}_{2} 1.3 \mathrm{l} / \mathrm{min}$, \\ Detector gain voltage : $1.8 \mathrm{Kv}$ \\ Probe voltage $: 5 \mathrm{Kv}$ \\ CDL voltage $\quad:-10 \mathrm{v}$ \\ HPLC Condition \\ Instrument :LC10AD (Shimadzu Corp.) \\ Column : Mightysil RP-18 (i.d. $2.0 \times 100 \mathrm{~mm}$ ) (Kanto Chemicals) \\ :Zorbax XDB-C18 (i.d. $2.1 \times 150 \mathrm{~mm} 5 \mu \mathrm{m}$ ) (Agilent Technologies) \\ Mobile Phase $: 0.001 \%$ Acetic acid $:$ Acetonitrile $=60: 40(\mathrm{~V} / \mathrm{V})$ \\ Flow rate $\quad: 0.2 \mathrm{m \ell} / \mathrm{min}$ \\ Column Temp. $: 40^{\circ} \mathrm{C}$ \\ Injection Volume :5 50 $\mu \ell$
}


で良く攪拌した)。

2 . 水冷時に超音波を 5 分間かけ，その後は 1 と同じ

3 . 水水から出し室温に戻した直後に超音波を 5 分間 かけ，その後は 1 と同じ

4 . 水水から出し室温に戻した後，室温に 3 時間保 持，その間30分ごとに超音波 5 分処理

5 . 水水から出し室温に戻した後, $40^{\circ} \mathrm{C}$ 水浴中で 3 時 間保持

\section{2.5 酸化分解生成物 (MMPB) の固相回収}

反応時間が経過した後，反応溶液に精製水 $4 \mathrm{~m} \ell$ お よび20\%亜硫酸水素ナトリウム $\left(\mathrm{NaHSO}_{3}\right)$ を過マンガ ン酸カリウムの色が消えるまで加え反応を停止した。

反応を停止した溶液に $2 \mathrm{M} \mathrm{H}_{3} \mathrm{PO}_{4}$ 約 $1 \mathrm{~m} \ell$ を均一に攪 找しながら添加し, 反応液の $\mathrm{pH}$ を 3 に調整した後, さらに内部標準物質としてサロゲート物質である MMPB $-d_{3} \quad 0.05 \mu \mathrm{g}$ を水溶液として添加した。この溶液 を固相カートリッジ（ジーエルサイエンス製 InertSep $\mathrm{RP}-1,30 \mathrm{mg} / 1 \mathrm{~m} \ell$, メ夕ノール $1 \mathrm{~m} \ell$, 精製水 $1 \mathrm{~m} \ell$ で 洗浄しておく）に穏やかに通液し，酸化分解生成物 (MMPB) を吸着させた。カートリッジを $1 \mathrm{~m} \ell$ の精製水 で洗った後， $0.2 \mathrm{~m} \ell$ の $90 \%$ メノール水溶液で MMPB
を溶出した（溶出液をスピッッ管に受ける）。さらに $0.2 \mathrm{~m} \ell$ の $90 \%$ メ タール水溶液， $0.6 \mathrm{~m} \ell$ の精製水をカー トリッジに通し，メタノールの残留液を押し出した。溶 出液と洗浄液をあわせ全量を $1 \mathrm{~m} \ell$ とし， LC/MS 用試料 とした (Fig. 2 )。

\section{2.6 環境試料からの回収実験}

アオコの塊を含む湖沼表層水を均一に攪找した試料 $50 \mathrm{~m} \ell$ をクリユーキャップ付遠沈管に取り，酢酸 $2.5 \mathrm{~m} \ell$ 加え, 密栓して超音波発生器（シャープ製 $\mathrm{U}$ 205S 200w）で3 分間処理した。処理後，20分間 $2500 \mathrm{rpm}$ で遠心分離し，上澄み液を採取した。残った残 渣にメタノール $10 \mathrm{~m} \ell$ を加えて，同様の操作を行い，上 澄み液を先のものと合わせた。

この溶液を固相カートリッジ（ジーエルサイエンス製

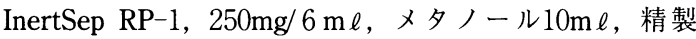
水 $20 \mathrm{~m} \ell て ゙$ 洗浄しておく）に通し，ミクロシスチンを吸 着させた。その後, 固相カートリッジを精製水 $20 \mathrm{~m} \ell$, $20 \%$ メノール水溶液 $20 \mathrm{~m} \ell$ で洗浄し， $80 \% （ \mathrm{v} / \mathrm{v}) \times$ 夕

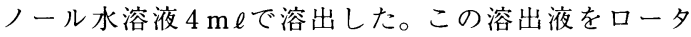
リーエバポレーターで $200 \mu \ell$ 程度まで濃縮し，MMPB 生成分解操作用試料液の検液とした（Fig. 2$) 。$

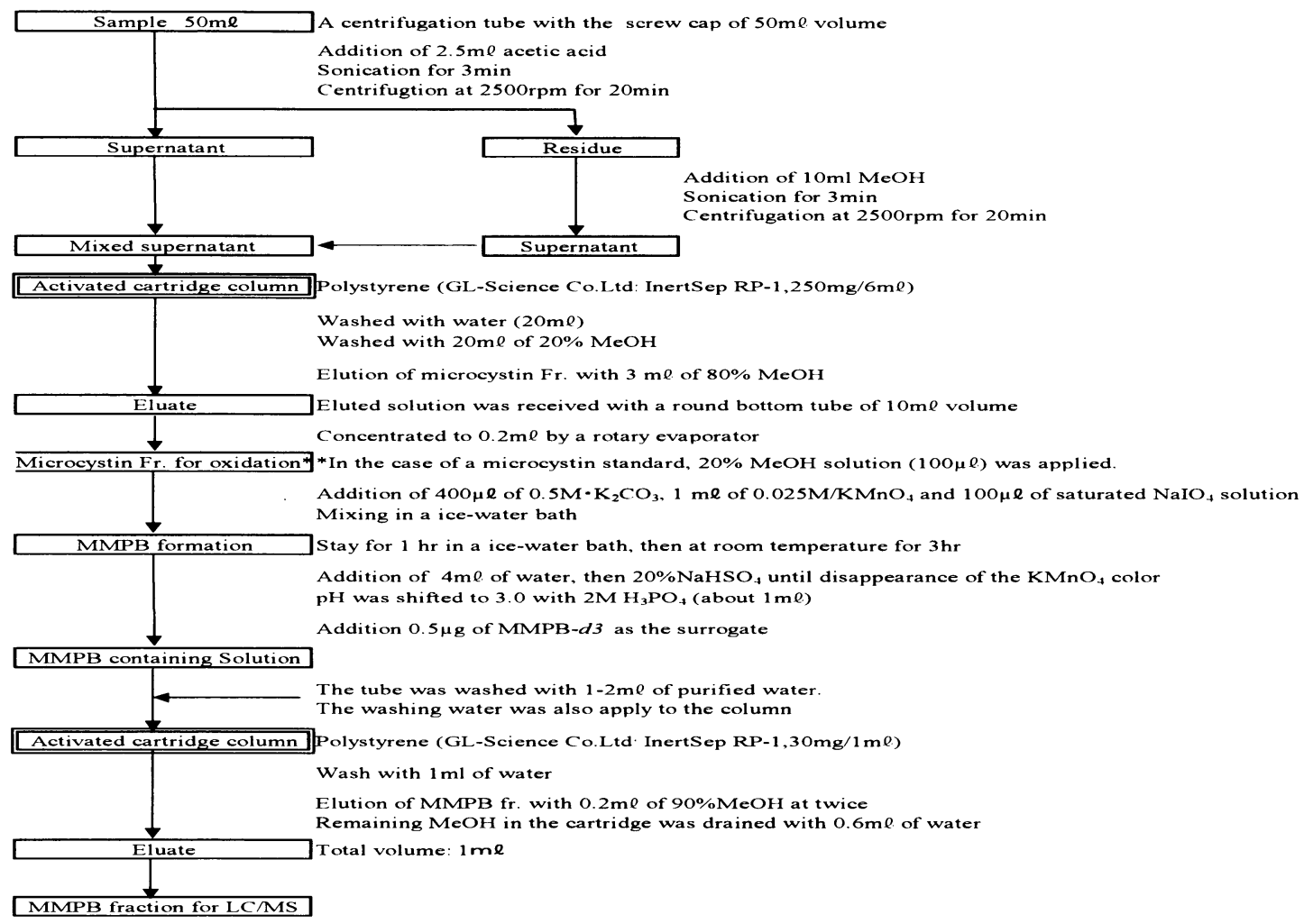

Fig. 2 Extraction of microcystins from environmental samples and MMPB formation procedure from microcystin 


\section{3. 結果と考察}

\section{1 MMPB 分析条件}

マススペクトルには, MMPBの親ピークと一致した $\mathrm{m} / \mathrm{z}=207$ のフラグメントピークが見られた。分析条件 によっては, MMPBに水の付加した分子量 $\mathrm{m} / \mathrm{z}=225$ の フラグメントが見られることもあったが，最終的な LC/MS の分析条件では検出されなかった。

移動相の $0.001 \%$ 酢酸/アセトニトリル濃度比を変化 させた場合のクロマトグラムを Fig. 3 に示す。MMPBの 分離およびピーク形状は，アセトニトリル濃度を $20 \%$ か ら $80 \%$ まで 6 分間で変化させた結果がもっとも良かっ た。しかし，分析時間等を考慮した結果，0.001\%酢酸／ アセトニトリル比を60：40の濃度比とした移動相条件で 測定することとした。固相からの回収率およびMSの感 度補正を行うためにサロゲート化合物を添加した。サロ ゲート化合物には MMPB-d3 $(\mathrm{m} / \mathrm{z}=210)$ を用いた。 MMPB- $d 3$ と MMPB の混合物のマススペクトル, SIM ク ロマトグラムを Fig. 4 に示す。

\section{2 MMPB の定量下限値}

MMPB の注入量を $160 \mathrm{pg}$ から $10 \mathrm{pg}$ まで変化させた結 果, $20 \mathrm{pg}$ までは変動係数（CV \%) は 5 \%以下で非常に 安定していた (Fig. 5 )。定量下限值を求めるために MMPB 注入量と CV \%の関係について回帰式を求めた。
回帰式より計算された CV10\%におけるMMPB の值は $11.83 \mathrm{pg}, 20 \%$ では $6.79 \mathrm{pg}$ であった。最小注入量である $10 \mathrm{pg}$ において CV \%が14.5\%であり，ピーク面積が約 30000 と感度が十分であった。このことから定量下限值 を10pgとした (Fig. 6)。MMPB注入量10pg から160pgの 間で，検量線は良い直線性を示した（Fig. 7 ）。

\section{3 ミクロシスチン-LR の酸化分解}

\section{3. 1 酸化剤添加量の検討}

従来は，固相カートリッジよりミクロシスチンを溶出 する際に入る溶出溶媒のメタノールの影響を避けるため に抽出した試料を一度乾固させていたが，再溶解時に完 全に溶解できずに収率のばらつきの原因となると推定さ れた。そこで試料を乾固することなくメタノールが一定 量含有した状態の検液のままで酸化分解を行った。

ミクロシスチン標準物質の酸化分解もメタノール $20 \%$ 水溶液のままで行ったが, メタノールにより酸化剂が消 費されるため酸化剤の量を増やす必要が認められた。酸 化剂の添加量を0.025M過マンガン酸カリウム $\left(\mathrm{KMnO}_{4}\right)$ ，飽和過よう素酸ナトリウム $\left(\mathrm{NaIO}_{4}\right)$ それぞ れの初期添加量 $500 \mu \ell, 50 \mu \ell$ から 2 倍, 3 倍及び 4 倍 と増加させた結果, 酸化試薬の量が 2 倍になると MMPB の収率がそれまでの $46 \%$ から $65 \%$ に大きく増加 した (Fig. 8$)$ 。その後の増加が比較的小さかったことか ら, 酸化剂の必要量をそれぞれ $0.025 \mathrm{M}$ 過マンガン酸カ

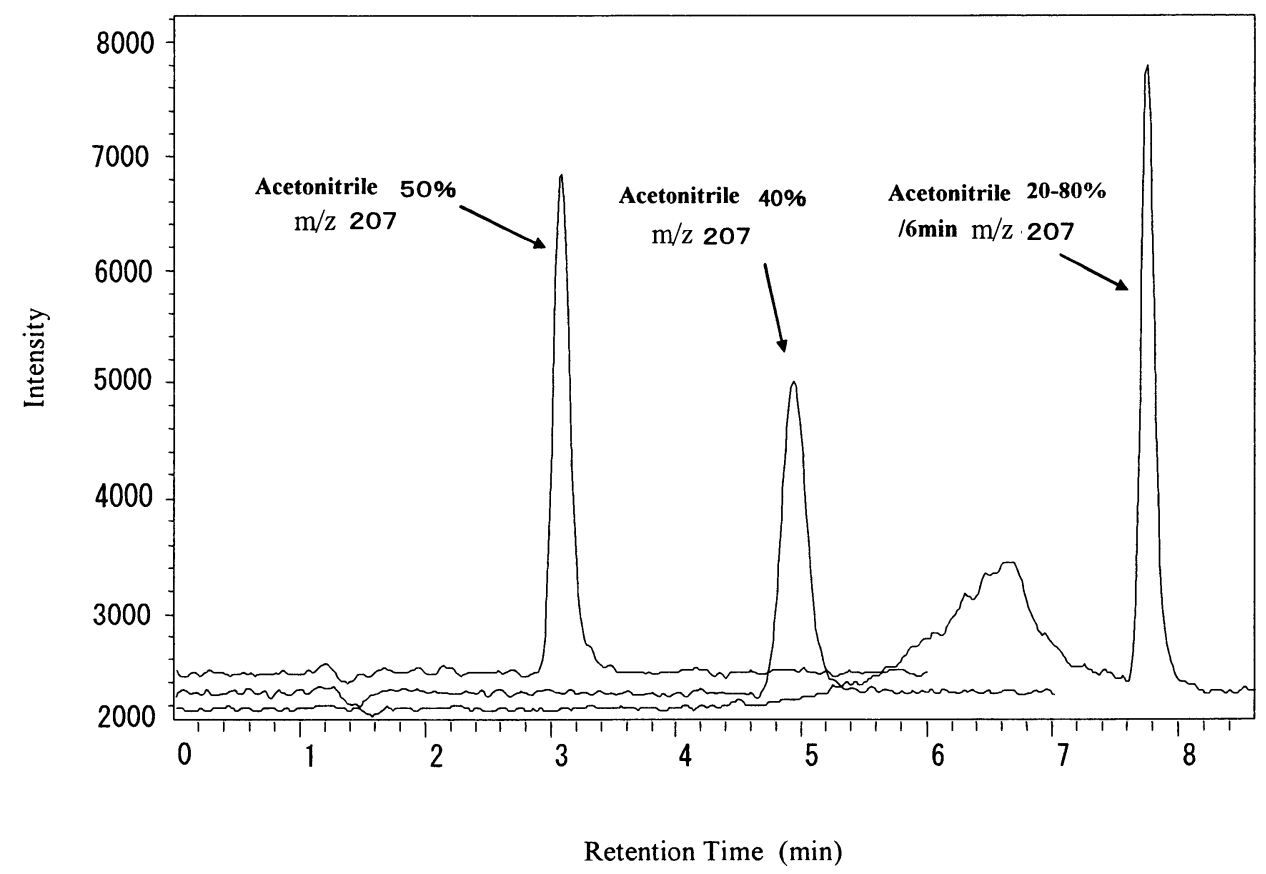

Fig. 3 Changes in MMPB mass chromatograms by various conditions of mobile phase for HPLC 
リウム $\left(\mathrm{KMnO}_{4}\right) 1 \mathrm{~m} \ell$, 飽和過よう素酸ナトリウム $\left(\mathrm{NaIO}_{4}\right) 100 \mu \ell$ とした。

従来, 過よう素酸ナトリウムは固体で加え反応溶液中 で溶解させていた ${ }^{13)}$ が, 速やかに溶解させることが困難
なために収率に影響を与える可能性が示唆されたため飽 和溶液として添加することとした。また，過よう素酸ナ トリウムは加水分解してアルカリ性を示し, その状態で 強い酸化力を示すため, 反応溶液を炭酸カリウムでアル
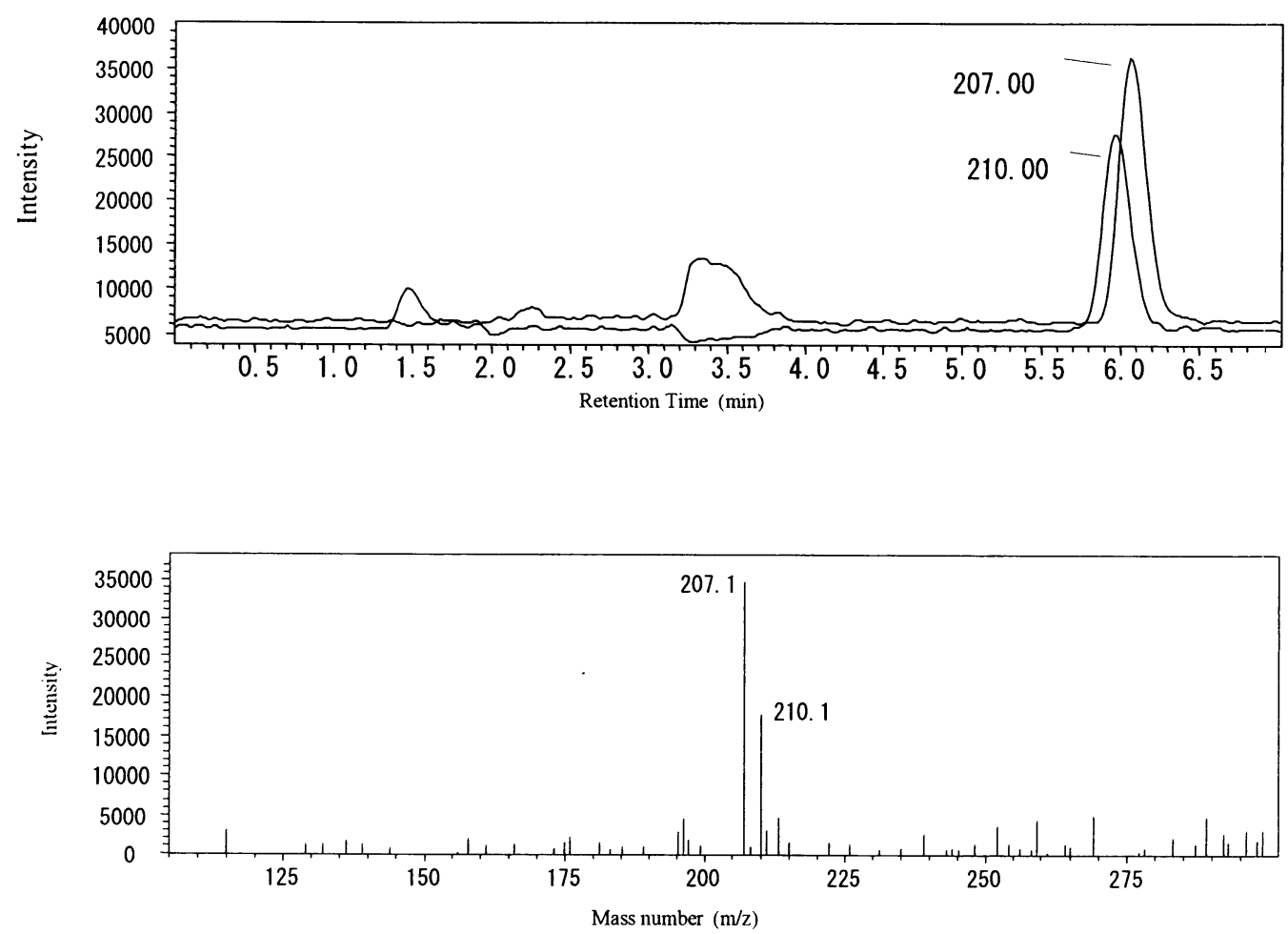

Fig. 4 Mass spectra and mass chromatograms of MMPB and MMPB-d3

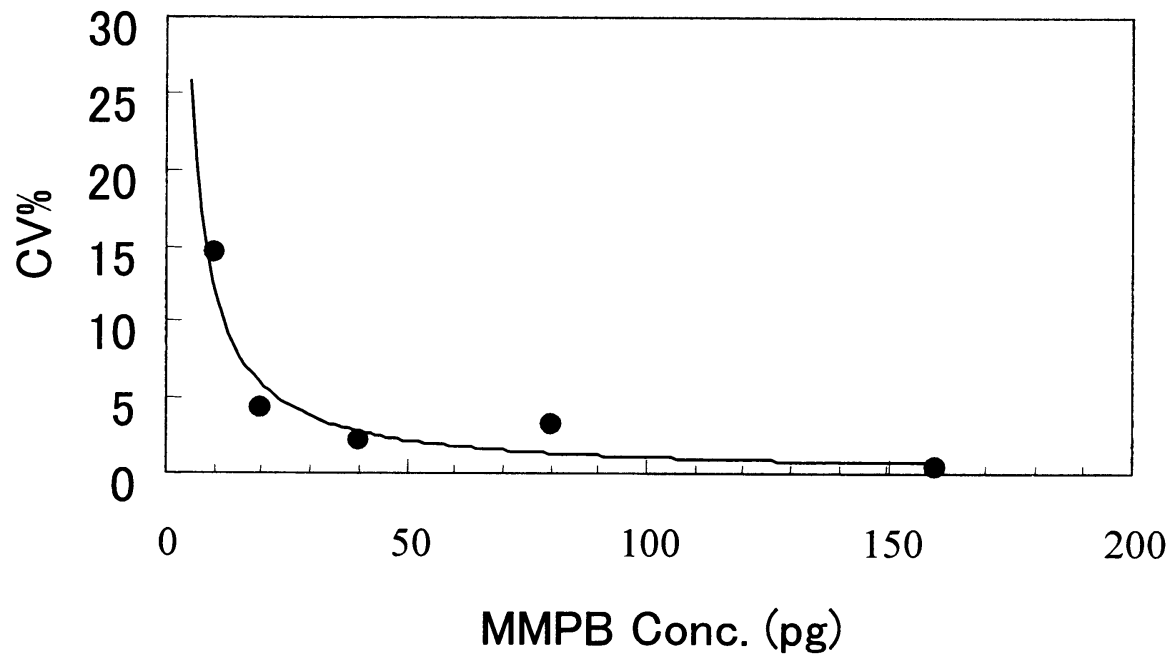

Fig. 5 Correlation diagram between MMPB concentration and the coefficient of variation 
カリ性にし，酸化力の安定性を高めた。

\section{3 . 2 酸化反応条件の検討}

酸化反応の攪汼条件および反応温度条件を変えて収率 への影響を検討したが，試料を乾固しない酸化反応条件
では，攪拌条件の違いによる収率に大きな差は見られな

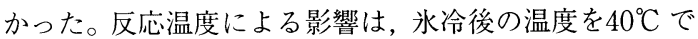
3 時間保持した条件では, 室温で保持した場合に比べ収 率に減少が見られた。
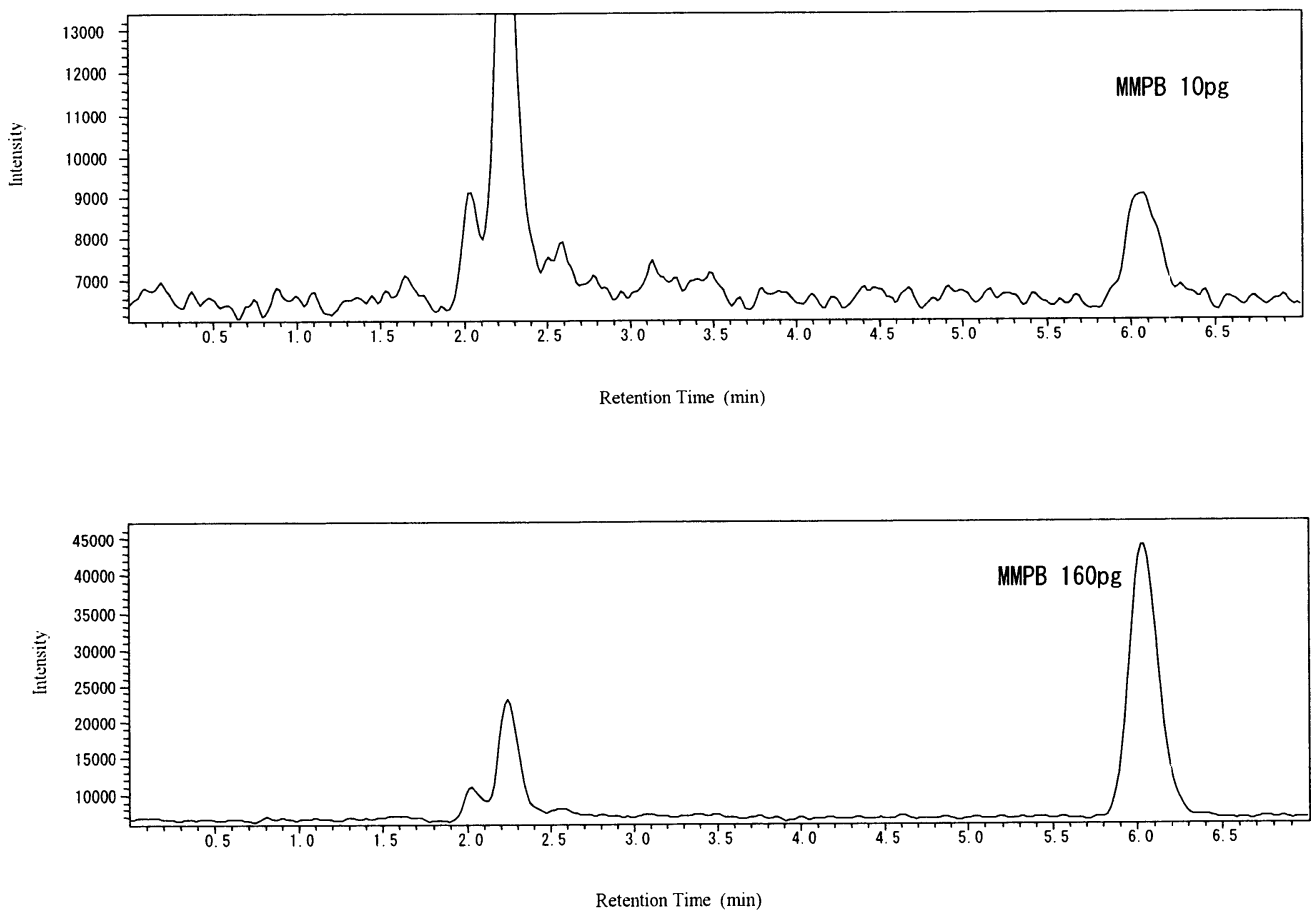

Fig. 6 SIM chromatograms of MMPB at the concentrations of $10 \mathrm{pg}$ and $160 \mathrm{pg}$

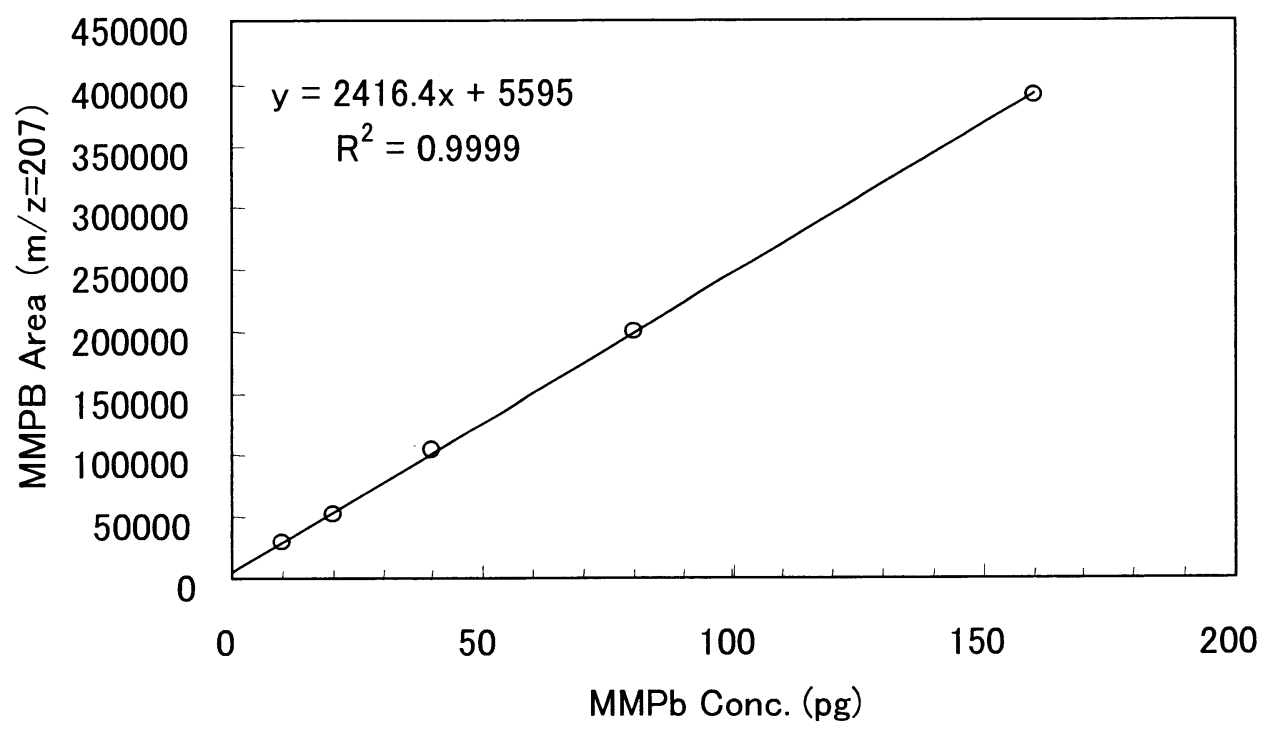

Fig. 7 A calibration curve of MMPB 


\section{3.3 酸化分解方法の検討結果}

ミクロシスチンの酸化分解で生成した MMPB は固相 抽出により回収されるが, 固相を通す溶液に $2.0 \mathrm{M}$ $\mathrm{H}_{3} \mathrm{PO}_{4}$ を加えて $\mathrm{pH} 3$ 以下 (約 $1 \mathrm{~m} \ell$ ) に調整した。その結 果, 回収率は60\%台から70\%台まで改善された。 MMPB- $d 3$ の回収率が $80 \%$ 台であることから, 分解効率 を含んだミクロシスチンからの MMPB の回収率として は十分なものと考えられた。

ミクロシスチン-LR 標準物質の分解試験を 1。乾固に よりメタノールを除去した後に酸化分解する方法（方法 1)，2．メタノールに溶解した状態で酸化分解する方 法（方法2）の 2 通りの方法について 3 濃度 $(0.25,0.5,1 \mu \mathrm{g} / \ell)$ で行ったところ, いずれの濃度 においても方法 2 が収率は最も高く, 方法 1 よりも収率 が高く, 平均収率は55\%から71\%に改善された (Fig. 9 )。

サロゲート物質である $\mathrm{MMPB}-d_{3}$ の希釈溶液は時間と ともに濃度が減少していくことが明らかとなった。その ため高濃度溶液で保存し, 使用の都度希棌調製した結 果，収率㧍よび回収率の再現性がさらに改善された。

ここで設定された分析条件で WHO のガイドライン值 $1 \mu \mathrm{g} / \ell$ を測定するために必要な試料の量を見積もると, 定量下限值 $10 \mathrm{pg}, \mathrm{LC} / \mathrm{MS}$ 注入量を $10 \mu \ell$, 全体の回収率 を $70 \%$ としたときに約 $10 \mathrm{~m} \ell$ の試料があればよいことが 明らかとなった。

\section{4 環境試料からの回収実験}

アオコの塊が含まれている湖水 $50 \mathrm{~m} \ell$ からミクロシ スチン抽出操作で調製された MMPB 測定用検液を 直接 LC/MS で測定した。TIC クロマトグラムを Fig.10-1 に示す。抽出されたミクロシスチン類の内ミクロシスチ ン-RR（m/z =520）のピークは検出できたが, ミクロシ スチン-LR（m/z=995）はわずかしか検出できなかっ た。

この溶液を検液としてMMPBを測定した結果を Fig.10-2に示す。この測定では，高濃度の MMPB が含ま れていると考えられたため, 内部標準物質の量を増やし 希釈した状態で測定を行った。この試料の MMPB 濃度 は, $14 \mu \mathrm{g} / \ell$ と求められた。

\section{4. まとめ}

1. LC/MS を用いた総ミクロシスチン量としての2-メ チルー3-メトキシー4-フェニル酪酸（MMPB）の定量 分析は, MSをネガティブESI 測定質量 $\mathrm{m} / \mathrm{z}=207$, 移動相を $0.001 \%$ 酢酸/アセトニトリル比60：40とす ることで良い分離測定が行えた。

2. 試料を乾固せずメタノールが一定量含有した状態で 酸化剂の量を0.025M過マンガン酸カリウム $\left(\mathrm{KMnO}_{4}\right) 1 \mathrm{~m} \ell$, 飽和過よう素酸ナトリウム $\left(\mathrm{NaIO}_{4}\right) 100 \mu \ell$ にて酸化し, $\mathrm{pH} 3$ の溶液で固相抽 出を行うことで収率は $71 \%$ になった。

3.これらの改良およびサロゲート化合物に MMPB- $d_{3}$

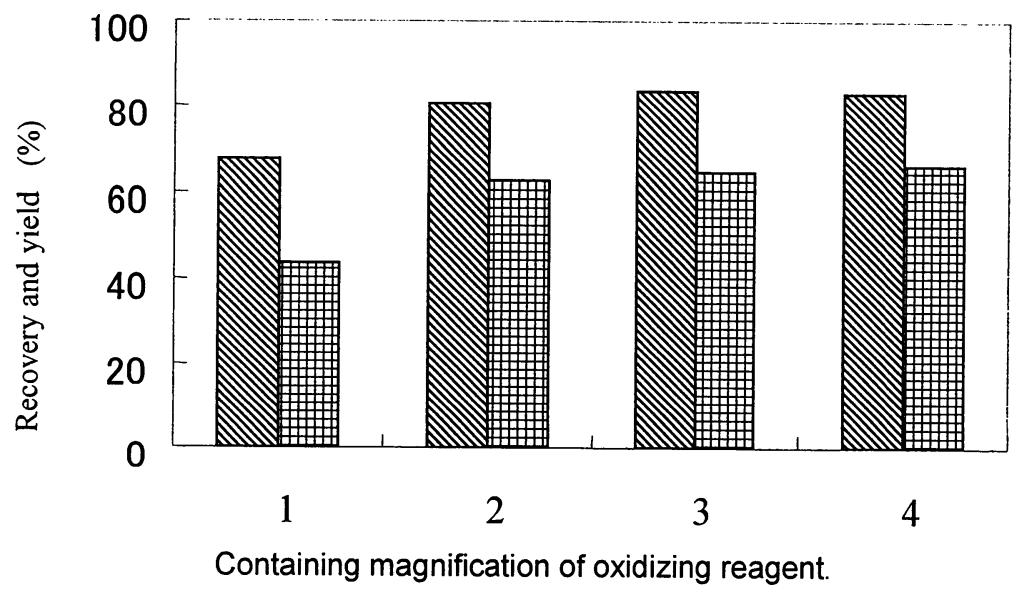

Fig. 8 Changes in yields and recoveries of MMPB by various amounts of the oxidizing reagents Original volumes of the oxidizing reagents; $0.025 \mathrm{M}$ Potassium permanganate $\left(\mathrm{KMnO}_{4}\right), 500 \mu \ell$;

Saturated sodium periodate $\left(\mathrm{NaIO}_{4}\right), 50 \mu \ell$.

Recovery of MMPB-d3

田 *Yield of MMPB 


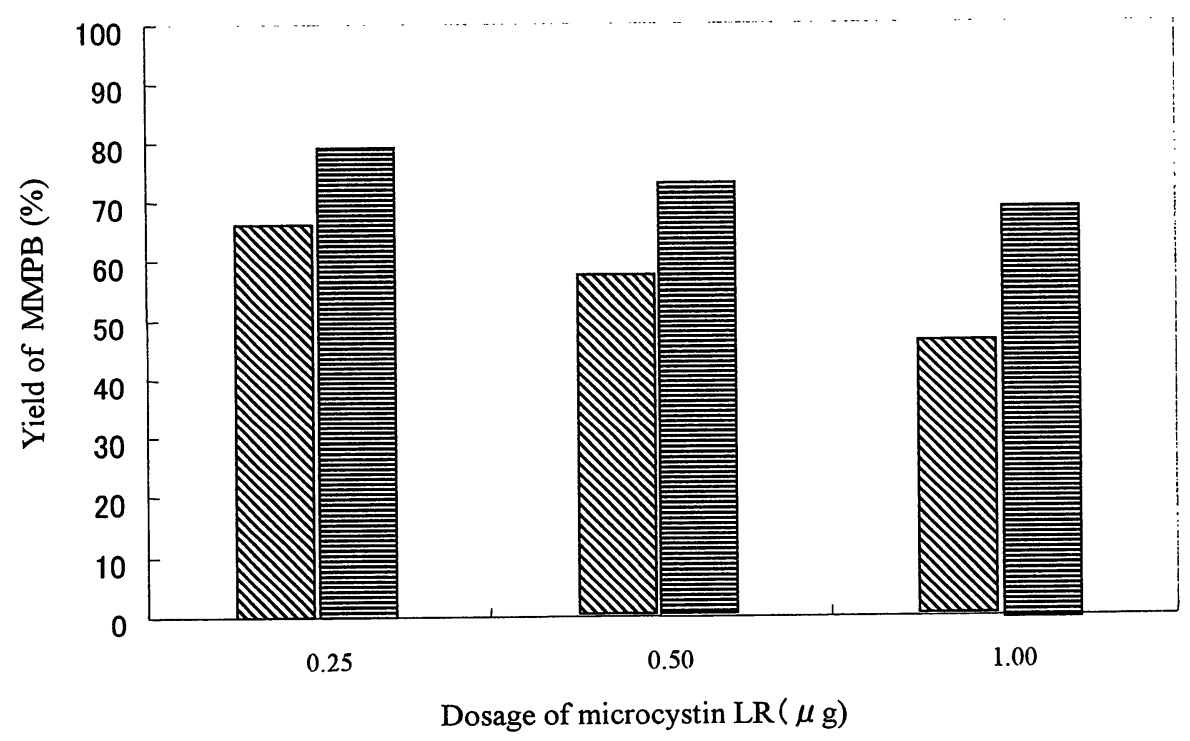

Fig. 9 Relationship between MMPB yields in the original and the improved methods Microcystin-LR was used for the experiment of MMPB yields. Noriginal method 豆 improved method
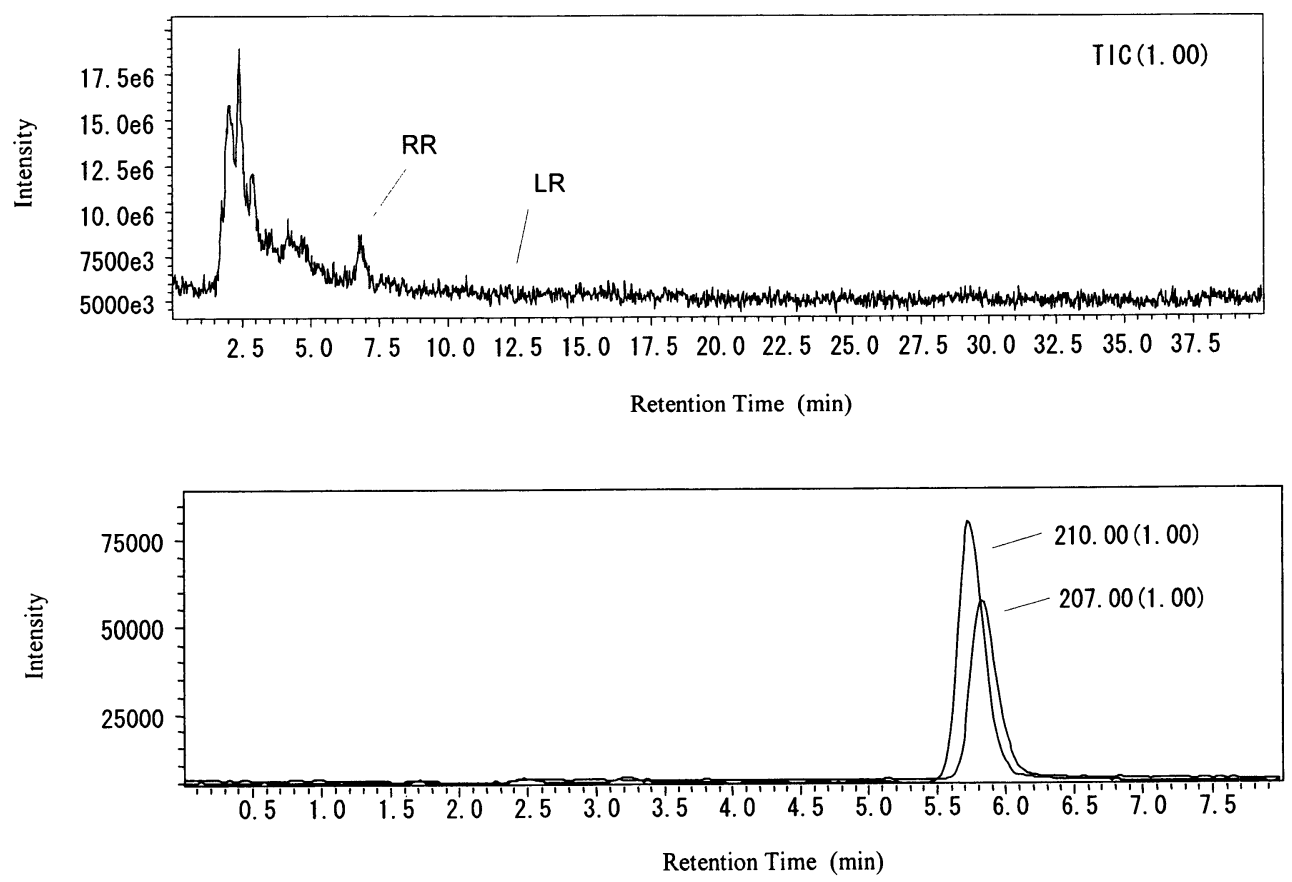

Fig. 10 Mass chromatograms of MMPB and microcystins from a environmental sample

10-1 Mass chromatogram of Microcystins from a environmental sample

10-2 Mass chromatogram of MMPB formed from the sample 
$(\mathrm{m} / \mathrm{z}=210)$ を用い回収率を補正した結果, ミクロ シスチン-LR の酸化分解過程も含めたMMPBの定 量下限值は10pg となった。

4. WHO ガイドライン值 $1 \mu \mathrm{g} / \ell$ の 10 分の 1 まで測定す るには $10 \mathrm{~m} \ell の$ 試料を濃縮すれば，検出限界を満足 できることから，今回検討した分析方法で $50 \mathrm{~m} \ell の$ 環境試料を用いれば WHO ガイドライン值の定量が 十分可能であることが明らかとなった。

\section{要 約}

LC/MSを用いた総ミクロシスチン量としての2-メチ ル-3-メトキシー4-フェニル酪酸 (MMPB) の定量分析 は, MSをネガティブ ESI 測定質量 $\mathrm{m} / \mathrm{z}=207$, 移動相 を0.001\%酢酸/アセトニトリル比60:40とすることで良 い分離測定が行えた。試料を乾固せずメ夕ノールが一定 量含有した状態で酸化剂の量を $0.025 \mathrm{M}$ 過マンガン酸カ リウム $\left(\mathrm{KMnO}_{4}\right) 1 \mathrm{~m} \ell$, 飽和過よう素酸ナトリウム $\left(\mathrm{NaIO}_{4}\right) 100 \mu \ell$ にて酸化し, pH 3 の溶液で固相抽出を行 うことで収率は $71 \%$ になった。WHO ガイドライン值 1 $\mu \mathrm{g} / \ell$ の 10 分の 1 まで測定するには50m $\ell$ の環境試料を用 いれば定量が十分可能であることが明らかとなった。

\section{文 献}

1) World Health Organization: Cyanobacterial toxins: Microcystin-LR. pp83-127, Guidelines for DrinkingWater Quality-Second Edition-Volume 2-Health Criteria and Other Supporting Information - Addendum, World Health Organization, Geneva (1998)

2) 彼谷邦光：3・6ミクロシスチンはどのような割合 で含まれているのか, pp43-44,「環境のなかの毒」, 裳華房, 東京 (1995)

3) Park, HD., Watanabe, MF., Harada, KI., Suzuki, M., Hayashi, H. and Okino, T.: Seasonal-Variations of Microcystis Species and Toxic Heptapeptide Microcystins in Lake Suwa. Environmental Toxicology and Water Quality, 8, 425-435 (1993)

4) Kaya, K. and Watanabe, M.M.: Microcystin of an axenic clonal strain of Microcystis viridis and Microcystis viridis-containing waterblooms in Japanese freshwater. J. Appl. Phycol., 2, 173-178 (1990)
5）彼谷邦光： $3 \cdot 5$ ミクロシスチンはどんな構造か。 またどのような性質か, pp37-43，「環境のなかの 毒」, 裳華房, 東京 (1995)

6) Rinehart, KL. Namikoshi, M., Choi, BW: Structure and biosynthesis of toxins from blue-green algae (cyanobacteria). J. Appl. Phycology 6, 159-176, 1994

7）彼谷邦光： 4 シアノトキシン, pp33-49,「飲料水に しのびよる有毒シアノバクテリア」, 裳華房, 東京 (2001)

8）日本水道協会：15ミクロキスティン, pp501-505, 「上水試験方法 2001版」, 日本水道協会, 東京 (2001)

9）滝埜昌彦，代島茂樹，中原武利：液体クロマトグラ フィー/質量分析法による河川水中のミクロシスチ ン類の分析法の検討, 環境化学, 11, 211-219, (2001)

10) Maizels, M. and Budde, W.L.: A LC/MS Method for the Determination of Cyanobacteria Toxins in Water. Anal. Chem. 76, 1342-1351 (2003)

11) Spoof, L., Vesterkvist, P., Lindholm, T. and Meriluoto, J.: Screening for cyanobacterial hepatotoxins, microcystins and nodularin in environmental water samples by reversed-phase liquid chromatographyelectrospray ionization mass spectrometry. J. Chromatography A, 1020, 105-119 (2003)

12) Robillot, C., Vinh, J., Puiseux-dao, S. and Hennion, M.: Hepatotoxin Production Kinetics of the Cyanobacterium Microcystins aeruginosa PCC 7820, as Determination by HPLC-Mass Spectrometry and Protein Phosphatase Bioassay. Environ. Sci. Technol, 34, 3372-3378 (2000)

13) Sano, T., Nohara, K., Shiraishi, F. and Kaya, K.: A Method for Micro-Determination of Total Microcystin Content in Waterblooms of Cyanobacteria (BlueGreen Algae). Intern. J. Environ. Anal. Chem, 49, 163-170 (1992)

14) Kaya, K. and Sano, T.: Total microcystin determination using erythro-2-methyl-3-(methoxy-d3)-4-phenylbutyric acid (MMPB-d3) as the internal standard. Analytica Chemica Acta 386, 107-112 (1999) 